\title{
The corporate credit rating changes and firm returns in a transitional economy: The case of South Africa
}

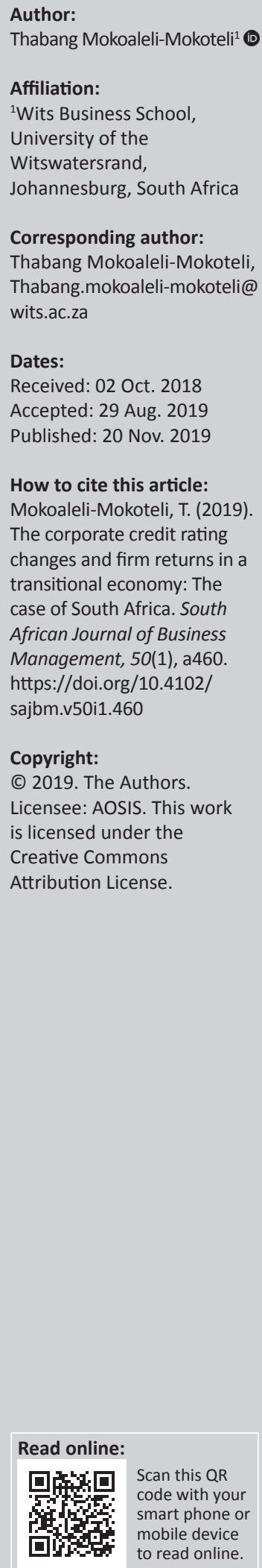

Background: Investors depend on rating agencies to provide an independent assessment of the ability of companies operating in the transition economy to meet their debt obligations. Any change in a firm's credit rating conveys informed signals about the financial health of the firm and that information should offer markets better knowledge about the future prospects of the firm's ability to pay creditors and equity holders. What we do not know is the magnitude of the impact of credit rating change on the stock yields of companies operating in a transitional and risky economy like South Africa. The literature indicates that the amount of influence that a rating agency has on equity returns is ambiguous.

Objectives: The purpose of this study is to determine whether companies' share prices react to a change in credit rating. The study also investigates the financial risk factors that differentiate between credit rating downgrades and upgrades.

Methods: The event study methodology was utilised to measure the abnormal returns of companies listed on the Johannesburg Stock Exchange (JSE) that had a credit rating change between 2005 and 2015. Logistic regression was used to establish the financial factors influencing the direction of credit rating change.

Results: We found that there was no significant impact evident on equity prices when companies' credit rating upgrades were announced by the credit rating agencies, indicating that the upgrades are largely anticipated by the market at the time they are announced. However, the market reacts significantly negatively when companies' credit rating downgrades are announced, suggesting that only credit rating downgrades contain relevant pricing information. The finding implies that the credit rating downgrades may lead to disinvestment from the economy, leading to deterioration in macroeconomic indicators in the country within which the firm operates. Furthermore, factors, including interest cover and firm earnings, are significant in differentiating between credit rating upgrades and downgrades, implying that debt issuers in South Africa can manage their credit rating by managing specific financial risk factors.

Conclusion: In an emerging and transitional economy like South Africa, the market reacts significantly negatively to credit rating downgrades, just as they do in developed countries like the USA. Stock prices react negatively to credit rating downgrades because credit rating agencies convey adverse private information about a company through these downgrades.

Keywords: Credit rating; rating upgrades and downgrades; financial metrics and rating; event study; market model; abnormal returns; stock markets; market efficiency.

\section{Introduction}

Different parts of the world have experienced economic transition. There are many different reasons for countries to embark on economic transformation. For example, the transition by Commonwealth of Independent States (CIS) and Central and Eastern European Countries (CEE) was meant to ensure that ownership of productive assets was moved away from the state towards individual owners. On the other hand, countries such as South Africa, Malaysia and the United States have experienced a slightly different kind of transition, which was both a political and an economic (i.e. socio-economic) transition within market-oriented economic systems. This latter type of transition was aimed at ensuring that previously disadvantaged people (black people in the United States and South Africa, and Malays in Malaysia) participated in the economies from which they had previously been excluded. Some past transitions have been characterised by a decrease in output, increased unemployment, hyperinflation, corruption, illegal activities and high levels of uncertainty (Marangos, 2003). These characteristics are true for South Africa as well. 
The emerging and transitional economies tend to also attract investors as they seek new horizons to diversify their portfolios and maximise their wealth (Kraussl, 2005) in a volatile and, therefore, risky environment. These investors then depend on rating agencies to provide an independent assessment of the ability of companies operating in the transition economy to meet their debt obligations. The rating agencies' view about companies operating within a transitional economy is therefore important for investors' economic decision-making, and any change in a firm's credit rating conveys informed signals about the financial health of the firm and that information should offer markets better knowledge about the future prospects of the firm's ability to pay creditors and equity holders (Ryan, Villupuram, \& Zygo, 2017). What we do not know is the magnitude of the impact of credit rating change on the stock yields of firms operating in a transitional and risky economy like South Africa, especially when Ryan et al. (2017) indicated that the amount of influence that a rating agency has on equity returns is ambiguous. Furthermore, credit rating agencies use various metrics to determine the credit rating upgrade or downgrade, but it is not entirely clear which of these metrics are significant in predicting the direction of credit rating for a firm operating within a transitional economy.

Numerous studies (e.g. Abad-Romero \& Robles-Fernandez, 2006; Dichev \& Piotroski, 2001; Hand, Holthausen, \& Leftwich, 1992; Micu, Remolona, \& Wooldridge, 2006; Ryan et al., 2017) sought to establish the relationship between credit ratings and the equity markets. The results of these studies vary significantly, based on the country researched. The differences in the results were also noted by Abdeldayem and Nekhili (2016) who asserted that research efforts directed at this relationship in specific countries would be ideal.

Understanding the impact of the credit rating on share prices in a transitional economy, as well as the factors that influence the direction of the credit rating, is important for various parties. For example, equity market participants, specifically asset managers and other investment professionals, would know if and how they should factor in the credit rating variable in their share valuation models.

The primary aim of the current study was to investigate whether specific firm rating change (upgrade or downgrade), which would typically change the bond yields, would have an impact on the firm's stock returns as well. The idea was to establish the extent to which bond yields impact on firm stock returns in a transitional economy like South Africa, which is characterised by high corruption levels, unemployment, high liquidity and a volatile currency. Understanding the impact of credit rating change is important as credit rating downgrades may result in institutional investors divesting from the firm, which, in turn, results in volatility in stock yields. Furthermore, the study aimed to understand the companies' financial characteristics that influence the credit rating change. Appreciating the real factors that influence credit rating downgrade or upgrade will help managers to know which variables are essential in the management of their credit rating.

The study contributes to the literature in two ways: Firstly, the study extends the existing literature (e.g. Ryan et al., 2017) on the credit rating impact of firm share price by showing that only credit rating downgrades have a significant impact on the stock yields of companies operating in risky and transitional economies like South Africa. Secondly, most previous studies (e.g. Abad-Romero \& Robles-Fernandez, 2006) analysed the market reaction to downgrades and upgrades but did not go further to establish the firm characteristics that significantly impact on the upgraded or downgraded credit rating in a transitional economy. The current study extends the literature by identifying the factors that significantly influence the firm's credit rating upgrade or downgrade in South Africa.

An event study methodology was used to assess the impact of the credit rating change. Only the extreme changes (category or level upgrade and downgrade) are considered because they hold new information that the market would typically react to as opposed to change within a level or watch list or reviews. The logistic regression was used to assess the firm financial characteristics that are significant in influencing the direction of the credit rating.

The rest of this article is organised as follows: The introduction section is followed by the literature review section. The next section discusses the methodology employed, followed by a section on the empirical findings. The last section discusses and concludes the research.

\section{Literature review}

Abad, Ferreras and Robbles (2018) state that credit rating agencies incorporate and transmit private information to investors in the market. De Haan and Amtenbrink (2011) summarise the role of credit rating agencies as twofold. Firstly, to provide an independent assessment of the debt issuer's ability to meet their debt obligations; and secondly, offer monitoring services through which they influence issuers to take corrective actions to avert downgrades via issuing of 'watch' procedure alerts.

Abad-Romero and Robles-Fernandez (2006) show that there are two main theories underlying the rating change announcements - information asymmetry and signalling hypothesis (IASH) and wealth distribution hypothesis (WDH). Information asymmetry and signalling states that, because rating agencies possess private information, their rating classifications may provide additional information to the market about a firm's total value. In addition, the credit rating change can be viewed as a signal to the market about future earnings and cash flow of the issuer. Information asymmetry and signalling was earlier proposed by Ederington, Yawitz and Roberts (1987) and enhanced by Caton and Goh (2003), who highlighted that the informative signal associated with 
rating adjustments had a pricing effect on the re-rated firm's rivals competing in the same industry, causing an intraindustry effect. However, Wakeman (1981) argued that the nature of the information being released by agencies is generally a summary of public information and as a consequence, in an efficient market, they should have no impact on asset prices.

Abad-Romero and Robles-Fernandez (2006) stated that the WDH focusses on the conflict of interest between bondholders and stockholders in that the existence of limited liabilities may encourage stockholders to increase their expected returns by taking riskier investments. The strategy of assuming additional risk to increase expected returns increases the default risk of outstanding bonds, which can be a reason for the rating downgrade. The rating downgrade would then reduce the bond value and investors would, in turn seek value in shares and thus cause the share price to increase. It is of interest to ascertain which of these two theories underlie the relationship between bonds and shares on the Johannesburg Stock Exchange (JSE).

In determining the credit rating of the issuer, the credit rating agencies consider and analyse the qualitative and quantitative factors around the firm. Incidentally, the factors considered in determining credit ratings are also largely the factors that inform the pricing of financial instruments. One of the key factors considered in the credit rating, and also in equity instrument pricing, is the robustness of the capital structure of the firm. Kisgen (2006) indicated that credit rating considerations affect the capital structure decisions by the management of firms. This conclusion is in support of Graham and Harvey (2001) who found that approximately $57.1 \%$ of the respondents consider credit rating when making the capital structure decisions.

Jorion and Zhang (2007) examined the changes in credit ratings by the three main credit rating agencies (Standard \& Poor's, Fitch and Moody's) and found that there are negative share abnormal returns for downgrades and positive share abnormal returns for upgrades, implying that credit rating downgrades result in share losses, whereas upgrades result in share gains. Dichev and Piotroski (2001) observed credit rating changes between 1970 and 1997, using the long-term effect method, and their findings were later matched by Jorion and Zhang (2007) who showed that the credit rating downgrades have significantly negative abnormal equity returns, but the finding that upgrades result in significantly positive returns was contradicted by Jorion and Zhang (2007). Avramov, Chordia, Jostova and Philipov (2009) established that at the time that companies are downgraded, they endure substantial equity price declines and institutional investors hurry to divest, especially if the rating is dropping to a speculative level.

Hite and Warga (1997) observed the impact of credit rating changes on 2800 bonds issued by 1200 firms and found that rating upgrades result in a positive effect on firm returns, specifically when a debt issue is upgraded from a speculative rating level to an investment grade in a specific month and a further 6 months preceding the event. However, other upgrades within the speculative grade or within the investment grade show weak evidence of the effects. The credit downgrades reflect a strong evidence of negative cumulative abnormal returns (CARs) for about 6 months prior to the event and also subsequent to the rating event.

Abad-Romero and Robles-Fernandez (2006) used the dummy variable regression method to assess the impact of rating on the asset prices in the Spanish stock market and revealed results contrary to the US studies. The study observed negative returns for upgraded firms and no significant returns for the downgraded firms. It is argued that these findings could be attributed to the $\mathrm{WDH}$, which suggests an inherent conflict between debt-holders' and equity-holders' interests. Thus, a credit rating downgrade results in a reduction of the bond value, which is transferred to stockholders, resulting in an increase in the equity price. The reverse would also apply for a credit rating upgrade. Goh and Ederington (1993) crystallised the WDH.

Kenjegaliev, Duygun and Mamedshakhova (2016) investigated the German stock market's reaction to credit rating changes and found that the Frankfurt Stock Exchange largely appears to anticipate announcements on rating changes. The study also found that the market tends to react more strongly to downgrades than upgrades. It is, however, noted that the information value of these rating announcements is negligible.

Poornima, Umesh and Reddy (2015) investigated the impact of ratings on the Indian stock market and found that ratings have an impact on equity prices. In particular, they found that the impact is more pronounced around the rating event date. The study further found that the impact is more prolonged and has a long-term impact on the value of companies. Creighton, Gower and Richards (2007) observed the impact of rating changes in the Australian market. The study concluded that credit rating announcements provide news to the market as they impact both the equity and bond markets.

The research on the impact of credit ratings has been done in various jurisdictions. We are not aware of a study that has been done in South Africa, and it is important to investigate whether the findings on the impact of credit rating on shares in South Africa will be similar to other emerging markets, such as India and China, or if it will be similar to developed economies, such as the United States and Europe.

Given the economic transitional stage, the low economic growth in South Africa and globally, and the need to access capital, it is important for managers to appreciate the factors that are important in the management of their credit ratings. The extant literature shows that there are various factors that influence a firm's credit rating, including financial and governance factors (e.g. Amato \& Furfine, 2004; Ashbaugh-Skaife, Collins, \& LaFond, 2006; Bhojraj \& Sengupta, 2003; Kim \& Sohn, 2008; Mittoo \& Zhang, 2008). In their most 
recent paper, Livingston, Poon and Zhou (2018) showed that about two-thirds to three-quarters of the variation in Chinese bond ratings can be explained by a dozen commonly used financial ratios and market-based variables, such as issuer's market capitalisation, interest coverage ratio and total debt ratio.

The findings in this article show that, consistent with the literature, even in transitional and volatile economies like South Africa, the market does not see much value in credit rating upgrades, but reacts significantly negatively to downgrades, making credit rating downgrades much more valuable to stockholders. The increased negative reaction could be a result of informational inefficiencies (Ryan et al., 2017) or the increased uncertainty arising from the environment, characterised by corruption, high unemployment and low economic growth. Furthermore, the findings confirm that it is possible to predict the direction of credit ratings using firm financial information and other characteristics (Livingston et al, 2018; Rogers, Mendes-da-Silva, \& Rogers, 2016).

\section{Research methodology Data and data sources}

The sample in this study comprised JSE-listed firms that are long-term debt issuers and / or have a long-term credit rating assigned by the external international rating agencies. The sample period was from 2005 to 2015 . The proposed time frame was considered ideal, as it provided indications of equity price reactions through the different cycles, inclusive of the 2008 credit crisis and the subsequent recession. The sample consisted of 155 credit ratings, which included ratings within rating categories, rating outlooks, reviews and credit rating level changes. In order to observe the market reaction to rating change, only extreme cases (rating category or level downgrade and upgrade) were included, which comprised 37 rating events with counterparties being constituents of various sub-indices on the JSE and operating in various sectors. The rationale for using the rating category changes instead of single or minimal rating changes within the rating band was consistent with the conclusion of the literature review that downgrades from the investment grade to non-investment grade or speculative ratings result in an even higher impact on the pricing of financial instruments (Hite \& Warga, 1997).

The financial data, including daily share price and credit rating, were obtained from Bloomberg and IRESS (previously INET BFA). The credit rating information was validated against the information from the respective credit rating agencies, including Standard \& Poor's, Moody's and Fitch. Only credit ratings for long-term instruments were included in the analysis. The Johannesburg Stock Exchange News Service (SENS) was checked for any significant events that could have influenced the share price on the rating event date, but there were no confounding effects observed during the change in the credit rating of
TABLE 1: Research sample.

\begin{tabular}{|c|c|c|c|c|c|c|}
\hline \multirow[t]{2}{*}{ Sample } & \multicolumn{2}{|c|}{ Downgrades } & \multicolumn{2}{|c|}{ Upgrades } & \multicolumn{2}{|c|}{ Total } \\
\hline & $n$ & $\%$ & $n$ & $\%$ & $n$ & $\%$ \\
\hline Original & 84 & 54 & 71 & 46 & 155 & 100 \\
\hline Adjusted & 19 & 51 & 18 & 49 & 37 & 100 \\
\hline
\end{tabular}

all 37 rating events. Table 1 presents information about the initial and final sample in this research.

Table 1 shows that the final sample consisted of more downgrades (54\% and 51\%, respectively) than upgrades (46\% and $49 \%$, respectively). Table 1 shows that over the sample period, most companies' default risk increased. The sample comprised a wide range of industries. Figures 1 and 2 demonstrate the industry segmentation for both credit rating upgrades and downgrades used in the analysis. Figures 1 and 2 indicate that financial institutions, in particular banks, constitute a significant portion of the sample. Having more banks in the sample is expected in South Africa as banks and state-owned companies are the main issuers of debt instruments. Mining and big industrial companies also play a big role in the South African debt market. State-owned entities are not listed on the JSE and therefore fall outside the ambit of this study. Banks made $39 \%$ of rating upgrades and $58 \%$ of the rating downgrades over the 10-year sample period.

\section{Research design}

The event study methodology was employed in this study to investigate the stock market reaction to changes in a firm's credit rating. The event study method tests the impact of a particular event on the share price of the firm by measuring the abnormal returns (performance) arising from the event. Various studies (e.g. Corrado, 2011; McWilliams \& Siegel, 1997) described the event study methodology as a valuable tool that researchers can use to analyse the impact of a specific event on a firm's financial metrics. As in Chi and Tang (2008), the idea was to estimate the direction and significance of the abnormal return attributable to the new and unexpected information contained in the credit rating change.

The short-term event window is chosen as, during a short term, it is less likely to have other confounding events that may impact on the share price. MacKinlay (1997), indicated that when daily data are used, the parameters for the market model (benchmark) methodology may be estimated by as much as over 120 days prior to the event. An estimation window of 180 days prior to the event window was chosen in this study. The estimation window was used to compute the beta and the intercept in the market model. The impact of the rating change was measured over 5 days before the event and 5 days after the event. Thus, the actual rating event happened at $\mathrm{t}=0$, the event window observed was between $\mathrm{t}-5$ and $t+5$, which denotes 5 days prior to and post the event.

The returns on the share price data is calculated using the geometric return formula as follows: 


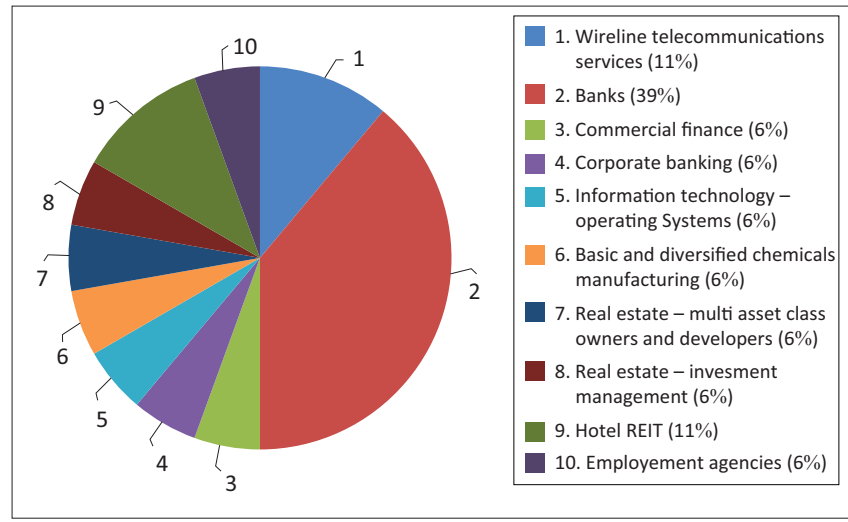

FIGURE 1: Industry categories for upgrades.

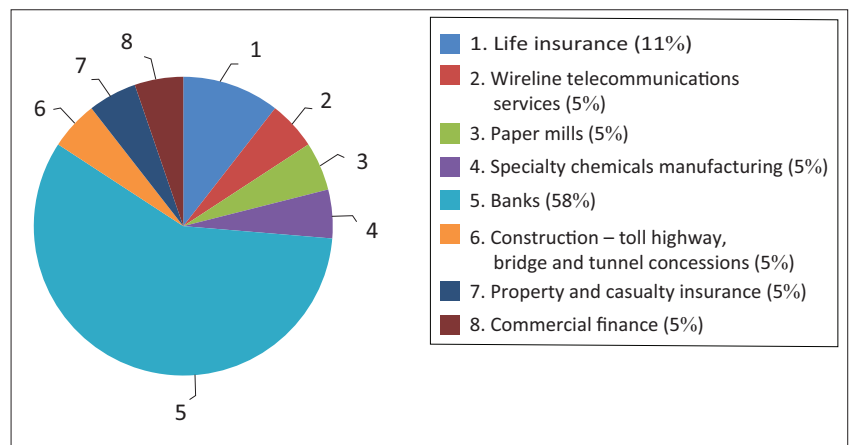

FIGURE 2: Industry categories for downgrades.

$\mathrm{R}_{\mathrm{it}}=\frac{\mathrm{P}_{\mathrm{it}}-\mathrm{P}_{\mathrm{i}, \mathrm{t}-1}}{\mathrm{P}_{\mathrm{i}, \mathrm{t}-1}}$

[Eqn 1]

Where:

- $\mathrm{R}_{\mathrm{it}}$ the actual stock return over the period $\mathrm{t}$;

- $\mathrm{P}_{\mathrm{it}}$ and $\mathrm{P}_{\mathrm{i}, \mathrm{t}-1}$ represent the stock price for the respective periods $t$ and $t-1$

The market model served as a benchmark of expected or normal returns (e.g. Harrington \& Shrider, 2007; Kenjegaliev et al., 2016). The JSE All Share Index was used as the proxy for the market return portfolio.

The market model is stated in the following equation:

$E\left(R_{i t}\right)=\alpha_{i}+\beta_{i} x\left(R_{m t}\right)$

[Eqn 2]

where:

$\mathrm{E}\left(\mathrm{R}_{\mathrm{it}}\right)=$ expected return of the stock on a specific day; $\alpha_{i}=$ alpha or intercept of the stock; $\beta_{\mathrm{i}}=$ beta value of the stock; and $\mathrm{R}_{\mathrm{mt}}=$ market returns. Alpha and Beta are obtained from Bloomberg over the estimation window period, whereas the market return is computed using the JSE All Share Index returns, also from Bloomberg.

To ascertain if the event results in the returns were beyond the expectation, the abnormal returns were computed by deducting the expected return (benchmark returns) from the actual or normal returns (firm returns):

$A R=R_{i t}-E\left(R_{i t}\right)$

[Eqn 3]
Where:

- $\mathrm{AR}=$ abnormal return;

- $\mathrm{R}_{\mathrm{it}}=$ the actual return of the stock on the day;

- $\mathrm{E}\left(\mathrm{R}_{\mathrm{it}}\right)=$ expected return on the stock for the respective day.

As in, for example, MacKinlay (1997) and Mokoteli-Mokoaleli, Taffler and Agarwal (2009), to draw inferences from the event being studied, observations made on abnormal returns were aggregated through the time period to determine cumulative abnormal returns (CARs). Cumulative abnormal return is the summation of the abnormal returns from the beginning of the period $t_{1}$, up to $t_{2}$. Cumulative abnormal return is specified as follows: $t_{2}$

$\mathrm{CARs}_{\mathrm{it}}=\sum_{t=t_{1}} \mathrm{~A}\left(\mathrm{r}_{\mathrm{t}}\right)$

[Eqn 4]

The credit rating change was considered to have a significant impact on the share returns if the subsequent abnormal returns were statistically significant at any conventional significance level.

In the second part of the analysis, the logistic regression was fitted to test the relationship between the firm's credit rating (downgrade or upgrade) and selected firm financial characteristics and metrics, mainly the metrics used by Moody's in assessing firms' credit rating (refer to www. moodys.com). The maximum likelihood estimation was used to estimate the model parameters.

The important assumptions of logistic regression are that there should not be influential observations in the data, and the independent variables need not be perfect linear combinations of each other. Pearson's residual was used to test for outliers and variance inflation factors (VIF), and tolerances were used to test for multicollinearity. There were no outliers observed and two variables were deleted (total liabilities and total debt) because their VIF were higher than 10.

The model is specified as follows:

$\operatorname{CREDIT}_{\text {RATING }}=\log \left(\frac{\pi}{1-\pi}\right)=\alpha+\beta_{1}\left(\right.$ FIRM_ABNORMALRET $\left._{\mathrm{j}, \mathrm{t}}\right)+$

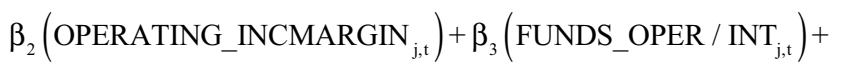
$\beta_{4}\left(\right.$ DEBT_OPERINC $\left._{\mathrm{j}, \mathrm{t}}\right)+\beta_{5}\left(\right.$ FCF $/$ DEBT $\left._{\mathrm{j}, \mathrm{t}}\right)+$

$\beta_{6}\left(\right.$ INTEREST_COVER $\left._{\mathrm{j}, \mathrm{t}}\right)+\beta_{7}\left(\right.$ NET_EARNINGSLOSS $\left._{\mathrm{j}, \mathrm{t}}\right)$

[Eqn 5]

Where:

- $\log \left(\frac{\pi}{1-\pi}\right)_{\mathrm{j}, \mathrm{t}}$ is the binary credit rating factor for the firm's new credit rating awarded to firm $j$ at time $t$. The credit rating is 0 if the firm's credit rating is downgraded, and 1 otherwise. 
- FIRM_ABNORMALRET ${ }_{\mathrm{j}, \mathrm{t}}=$ excess stock return of firm $\mathrm{j}$ at time t.

- OPERATING_INCMARGIN ${ }_{j, t}=$ the revenue balance of firm $j$ after paying for all operating expenses at time $t$.

- FUNDS_OPER/INT ${ }_{j, t}=$ firm j's ability to meet its interest payment in time $\mathrm{t}$ from cash flow before changes in working capital and other short-term operating assets.

- DEBT_OPERINC ${ }_{\mathrm{j}, \mathrm{t}}=$ income available of firm $\mathrm{j}$ at time $\mathrm{t}$ to pay the firm's debts.

- FCF $/$ DEBT $_{i, t}=$ the uncommitted cash available to firm $j$ to pay the debt at time t.

- INTEREST_COVER I $_{i, t}=$ firm j's ability to pay the debt at time $t$.

- NET_EARNINGSLOSS $_{\mathrm{j}, \mathrm{t}}=$ firm j's profitability at time $t$.

\section{Empirical findings and analysis Univariate analysis}

The rating agencies use different measures, such as potential future earnings of the firm and debt ratios, to assess the deterioration or the improvement in the default risk of the firm. Table 2 presents the univariate statistics about financial characteristics of companies that received credit rating upgrades and downgrades at the time that the credit rating was changed.

Table 2 shows that the financial measures of downgraded firms (except for DEBT_OPERINC and TOTAL_LIABILITIES) were better than those of the upgraded firms. The DEBT OPERINC and TOTAL_LIABILITIES measures were better for firms that were upgraded than those that were downgraded with a DEBT_OPERINC mean of 4.3549 $($ median $=3.0387)$ for upgrades versus 3.1966 (median $=$ 2.6408) for downgrades and TOTAL_LIABILITIES mean of R234 620 billion (median $=$ R8642) for upgrades versus R432

TABLE 2: Financial characteristics of firms that had a rating action (upgrades and downgrades).

\begin{tabular}{|c|c|c|c|c|}
\hline Panel & Mean & Median & $\operatorname{SD}(\sigma)$ & Skewness \\
\hline \multicolumn{5}{|l|}{ Panel a: Rating upgrades } \\
\hline FIRM_ABNORMALRET (\%) & 0.0010 & -0.0011 & 0.0229 & 1.5502 \\
\hline OPERATING_INCMARGIN (\%) & 0.2160 & 0.2325 & 0.1429 & 0.2382 \\
\hline FUNDS_OPER/INT (\%) & 5.1903 & 2.8512 & 6.6906 & 1.9176 \\
\hline DEBT_OPERINC (\%) & 4.3549 & 3.0387 & 4.8078 & 2.1579 \\
\hline FCF/DEBT $(\%)$ & 0.3229 & 0.2108 & 2.1226 & -3.7023 \\
\hline FUNDS_OPER/DEBT (\%) & 3.1362 & 0.1816 & 1.5754 & -3.1360 \\
\hline INTEREST_COVER (\%) & 5.2466 & 1.2524 & 6.9821 & 1.6089 \\
\hline NET_EARNINGSLOS(R' billions) & 3917.40 & 708.86 & 4977 & 0.9449 \\
\hline TOTAL_LIABILITIES (R' billions) & 234620 & 8642 & 422785 & 1.6305 \\
\hline \multicolumn{5}{|l|}{ Panel b: Rating downgrades } \\
\hline FIRM_ABNORMALRET (\%) & 0.0023 & 0.0019 & 0.0084 & -0.6618 \\
\hline OPERATING_INCMARGIN (\%) & 0.2365 & 0.2589 & 0.1674 & 0.2184 \\
\hline FUNDS_OPER/INT (\%) & 9.7267 & 2.8372 & 21.364 & 3.6248 \\
\hline DEBT_OPERINC (\%) & 3.1966 & 2.6408 & 13.1205 & -2.1850 \\
\hline FCF/DEBT $(\%)$ & 0.5565 & 0.3590 & 0.7796 & 0.3269 \\
\hline FUNDS_OPER/DEBT (\%) & 0.6934 & 0.5165 & 0.7726 & 0.2541 \\
\hline INTEREST_COVER (\%) & 6.2436 & 0.89284 & 11.306 & 1.8491 \\
\hline NET_EARNINGSLOS(R' billions) & 85970 & 7742 & 10242 & 1.5108 \\
\hline TOTAL_LIABILITIES(R' billions) & 432733 & 133143 & 458702 & 0.6154 \\
\hline
\end{tabular}

SD, standard deviation. 733(median=133 143) for downgrades. Thus, for as long as the firm debt is high and the firm shows signs of deterioration in its ability to cover the debt with its operating income, it would be downgraded even if the stock market performance and operating profit margins were comparatively better. This indicates that not all financial measures have to be bad for companies to be downgraded but only selected variables matter.

\section{Stock market reaction to credit rating upgrades and downgrades}

The CARs were observed over a period of 5 days before and 5 days after the credit rating change. The objective is to establish whether credit rating change had any impact on the share return. Table 3 presents information about share abnormal returns when the firms' credit ratings were upgraded.

The results in Table 3 show that the mean CAR for credit rating upgrades was positive throughout the window period but not significant at any conventional level, implying that the credit rating upgrades had no impact on the firm's share returns. These findings corroborate with other studies, including Ryan et al. (2017).

Figure 3 graphically presents the market reaction on rating upgrades throughout the window period using both

TABLE 3: Abnormal returns measure for credit rating upgrades.

\begin{tabular}{lccccc}
\hline Days & Mean CARs (\%) & Median (\%) & SD & $\boldsymbol{t}$ & $\boldsymbol{p}$ \\
\hline-5 & 0.0002 & 0.0006 & 0.002 & 0.0864 & 0.5339 \\
-4 & 0.0014 & 0.0003 & 0.005 & 0.2946 & 0.6139 \\
-3 & 0.0050 & 0.0006 & 0.002 & 2.4692 & 0.9874 \\
-2 & 0.0114 & 0.0012 & 0.004 & 2.6643 & 0.9915 \\
-1 & 0.0091 & -0.0021 & 0.002 & 3.7360 & 0.9991 \\
0 & 0.0102 & -0.0011 & 0.005 & 1.9313 & 0.9643 \\
1 & 0.0158 & 0.0050 & 0.003 & 5.2326 & 1.0000 \\
2 & 0.0129 & -0.0077 & 0.006 & 2.2607 & 0.9810 \\
3 & 0.0136 & 0.0001 & 0.004 & 3.5896 & 0.9988 \\
4 & 0.0141 & -0.0006 & 0.003 & 4.2964 & 0.9997 \\
5 & 0.0151 & -0.0006 & 0.003 & 5.3930 & 1.0000 \\
\hline
\end{tabular}

CARs, cumulative abnormal returns; SD, standard deviation.

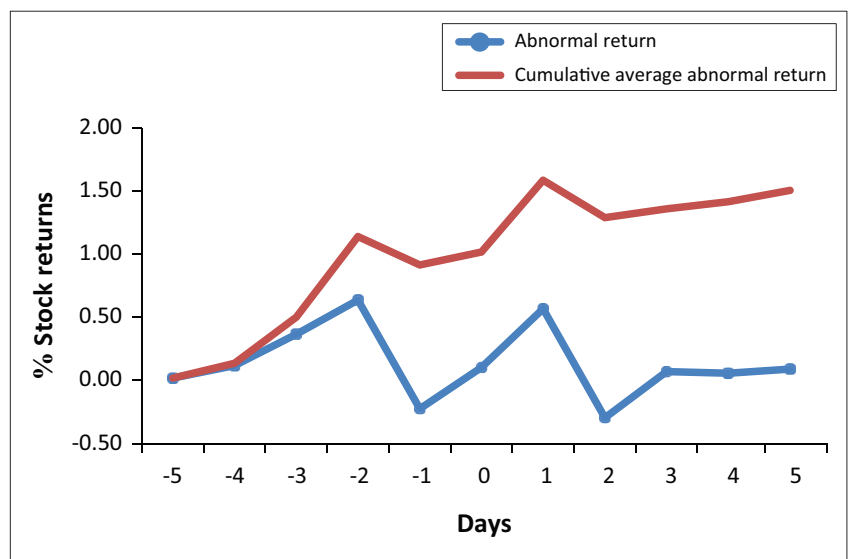

FIGURE 3: Abnormal returns' and cumulative abnormal returns' performance on credit rating upgrades. 
abnormal returns and CAR. The CAR increased to about $1.50 \%$ over the sample period, but the increase was not statistically significant.

Table 4 shows that the market reacts significantly negatively to credit rating downgrade news about 3 days before the actual announcement. The market's significantly negative reaction continues up to 5 days after the downgrade announcement has been made. The results generally show that the JSE takes a few days to assimilate the negative news associated with credit rating downgrades.

Figure 4 graphically illustrates how the market reacts to credit rating downgrades and gives a more visual representation of how the market reacts to the bad news.

Figure 5 depicts the comparative movement of the stock market when the firm's credit rating is downgraded and upgraded. Figure 5 shows that the market reacts significantly negatively to negative news of credit rating downgrades, while on the other hand, upgrades resulted in positive, albeit insignificant, CAR, implying that rating

TABLE 4: Abnormal returns measure for downgrades.

\begin{tabular}{lccccc}
\hline Days & Mean CARs (\%) & Median (\%) & SD & $t$ & $p$ \\
\hline-5 & 0.0036 & 0.0020 & 0.003 & 1.1276 & 0.8614 \\
-4 & -0.0036 & -0.0038 & 0.004 & -0.8902 & 0.1937 \\
-3 & -0.0061 & -0.0016 & 0.002 & -3.0123 & $0.0044^{*}$ \\
-2 & -0.0124 & -0.0052 & 0.004 & -3.2018 & $0.0030^{*}$ \\
-1 & -0.0076 & 0.0040 & 0.003 & -2.2766 & $0.0190^{* *}$ \\
0 & -0.0050 & 0.0026 & 0.002 & -2.1709 & $0.0232^{* *}$ \\
1 & -0.0142 & -0.0031 & 0.004 & -3.1856 & $0.0031^{*}$ \\
2 & -0.0119 & 0.0029 & 0.004 & -2.9034 & $0.0055^{*}$ \\
3 & -0.0162 & -0.0026 & 0.007 & -2.3385 & $0.0168^{* *}$ \\
4 & -0.0147 & 0.0075 & 0.006 & -2.6059 & $0.0099^{*}$ \\
5 & -0.0127 & 0.0022 & 0.002 & -5.0950 & $0.0001^{*}$ \\
\hline
\end{tabular}

CARs, cumulative abnormal returns; SD, standard deviation.

$*, 1 \%$ significant level; **, $5 \%$ significant level. upgrades do not bring any new information to the market, but rating downgrades bring about significant adverse movement in the equity prices.

\section{Factors that influence the firm credit upgrades and downgrades}

The logistic regression was fitted to determine which factors differentiated between the credit rating downgrades and upgrades. The dependent variable is: credit rating $=0$ if the rating is upgraded; credit rating $=1$ if the rating is downgraded. The model was based on downgrades.

Table 5 shows that the coefficient of interest cover was positive and significant at the $10 \%$ level, implying that there were increased odds of receiving a downgrade from rating agencies if companies' interest cover change. The coefficient for a free cash flow divided by debt and net earnings loss/profit was negative at the $5 \%$ level, implying that the odds of a downgrade are lower if a firm's cash flow in relation to debt and earnings increased.

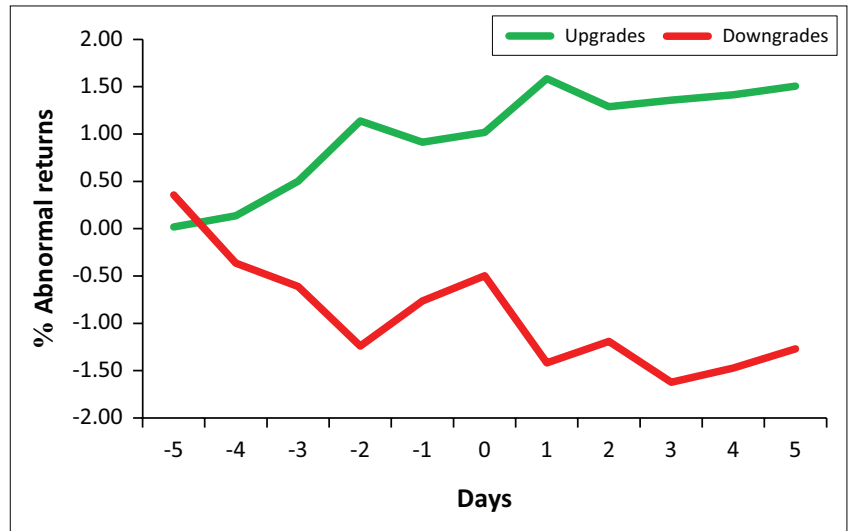

FIGURE 5: Cumulative abnormal returns for each rating action (upgrades and downgrades).

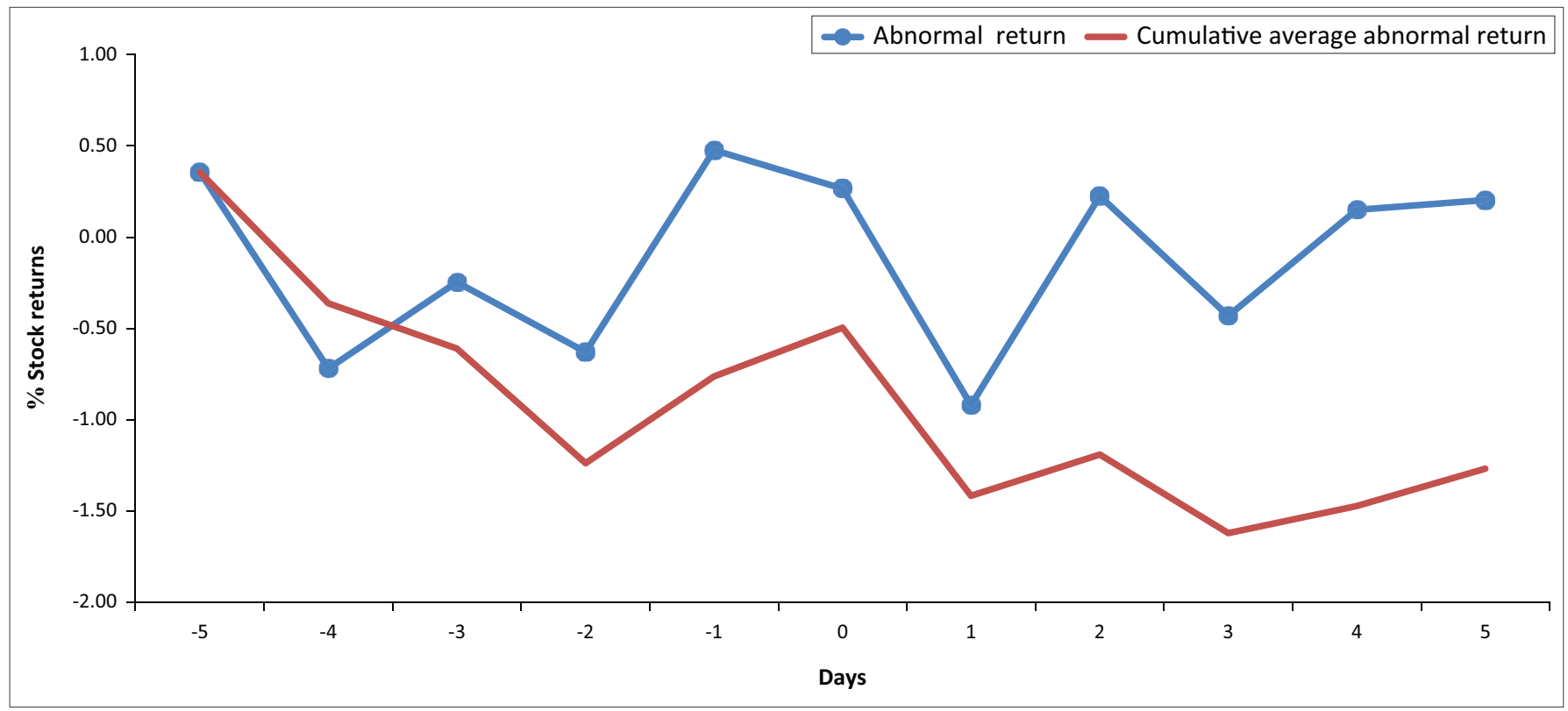

FIGURE 4: Abnormal returns and cumulative abnormal returns on credit rating downgrades. 
TABLE 5: Financial measures influencing credit rating upgrades and downgrades.

\begin{tabular}{lcccc}
\hline Parameter & Estimate & $\begin{array}{c}\text { Wald } \\
\text { chi-square }\end{array}$ & $\begin{array}{c}\text { Pr }> \\
\text { chi-square }\end{array}$ & Variable \\
\hline Abnormal_Return & -17.8721 & 0.5415 & 0.4618 & - \\
Operating_Income_Mar & 5.7846 & 2.3252 & 0.1273 & - \\
Funds_from_Operation/debt & -0.0797 & 0.6382 & 0.4244 & - \\
Debt_to_EBITDA & -0.0097 & 0.0069 & 0.9340 & - \\
Free_Cash_Flow_Debt & -4.7635 & 3.6798 & $0.0551^{* *}$ & - \\
Funds_from_Operation & 2.6411 & 1.7060 & 0.1915 & - \\
Interest_Cover & 0.1798 & 2.7501 & $0.0973^{* * *}$ & - \\
Net_Earnings_Loss & -0.0002 & 5.1614 & $0.0231^{* *}$ & - \\
Likelihood ratio $X^{2}$ & - & - & - & 13.3991 \\
$X^{2}$ significance $(p$-value $)$ & - & - & - & 0.0988 \\
\hline
\end{tabular}

EBITDA, Earnings before interest, tax, depreciation and amortization; $\mathrm{Pr}$, probability

$* *, 5 \%$ significant level; ***, $10 \%$ significant level.

Overall, as expected, these findings show that liquidity (as measured by FCF/DEBT and NET_EARNINGSLOSS) and solvency (as measured by INTEREST_COVER) play a major role in influencing the credit rating of a firm. The FIRM_ABNORMALRET estimate was insignificant, implying that any change in the share returns of the firm does not have any impact on whether the credit rating of the firm is downgraded or upgraded. The likelihood ratio chi-square was 13.39 , significant at the $10 \%$ level, indicating that the model was a good fit.

The findings corroborated with the previous literature (e.g. Kim \& Sohn, 2008), which argued that the financial risk using various measures is important in determining the credit rating of the firm and, therefore, managers need to manage these measures carefully to manage their credit rating.

\section{Ethical consideration}

This article followed all ethical standards for a research without direct contact with human or animal subjects.

\section{Discussion}

The aim of this study was twofold: One, to investigate how the stock market reacts to credit rating upgrades and downgrades, and in doing so, to establish the relationship between bond yields and stock returns. Two, to use a logistic regression model to determine the financial measures or metrics that differentiate between credit rating, downgrades and upgrades.

The findings indicate that the credit rating upgrades do not have any impact while the credit rating downgrades bring about a significant market underreaction in stock prices. This observation suggests that rating upgrades are largely anticipated by the market at the time that they are announced and, therefore, they do not have a significant impact on the share price. On the other hand, the credit rating downgrades provide new sensitive information to the market. The reaction to credit rating downgrades refutes the efficient market hypothesis (EMH), which suggests that share prices react immediately to new information. The analysis of the factors that differentiate between credit rating downgrades or upgrades show that liquidity and solvency measures play a significant role in increasing or decreasing the odds of downgrades and upgrades.

The findings of this study corroborate with the findings of Poornima et al. (2015), Dichev and Piotroski (2001), Jorion and Zhang (2007) and Ryan et al. (2017) who found positive, but insignificant, average abnormal returns following a rating upgrade. The result of the current study is also consistent with the findings of Hite and Warga (1997), Creighton et al. (2007), Avramov et al. (2009), Ferreira and Gama (2007) and Kenjegaliev et al. (2016) who all found that credit rating upgrades contain no new information, or, if any, they contain very insignificant information consumed by capital markets. Most of the studies, including Abdeldayem and Nekhili (2016), Poornima et al. (2015), Kenjegaliev et al. (2016) and Creighton et al. (2007), also argue that the most pronounced impact found on credit ratings is on the rating downgrades, which suggest that downgrades contain more valuable information for the market than upgrades. The findings in this study corroborate with these studies by showing that the downgrades have price-sensitive information, even in transitional emerging markets like South Africa.

The findings in this study are different from that of AbadRomero and Robles-Fernandez (2006) who observed negative abnormal returns for upgraded companies. On one hand, Abad-Romero and Robles-Fernandez (2006) explained their findings through the WDH, which highlights the conflict of interest between bondholders and stockholders in that, the existence of limited liabilities may encourage stockholders to increase their expected returns by taking riskier investments. The strategy of assuming additional risk to increase expected returns increases the default risk of outstanding bonds, which can be a reason for the rating downgrade. On the other hand, the findings in the current study support the IASH which posits that rating agencies possess private information that impacts on firm value.

The fact that financial measures, such as interest cover, cash flows and firm earnings, can differentiate between the firm's credit upgrades and downgrades corroborate with the findings of, for example, Kim and Sohn (2008) and Rogers et al. (2016), who found that certain firm financial measures are significant in predicting credit rating change. The results imply that corporate managers can manage their credit rating effectively by managing certain specific financial metrics in a firm.

\section{Conclusion}

The relationship between credit rating change and stock yields is ambiguous and varies significantly, based on the country being researched. In an emerging and transitional economy like South Africa, the market reacts significantly negatively to credit rating downgrades, just as they do in developed countries like the United States. Stock prices react negatively to credit rating downgrades because credit rating agencies convey adverse private information about a company through these downgrades. As a result, equity holders who 
believe that the credit rating downgrade will impede the future earnings and cash flows of the firm may choose to divest and invest where the stock yields will be higher. The divestment often increases the size and volatility of emerging markets' lending, which would, in turn, compromise the macroeconomic indicators, including economic growth and the employment rate.

Furthermore, the current stock yield of the firm that received the credit rating change does not have any significant impact on firm credit rating change, but balance sheet measures of credit risk do have an impact, implying that the balance sheet of the firm is more important than stock market indicators when it comes to understanding the influence of the credit rating change in South Africa.

Further research could investigate the market reaction to the different types of debts issues as well as the informational transfer effect of bond rating change on industry rivals in emerging markets.

\section{Acknowledgements}

The author thanks Jenny Croll for assistance in editing the article and the 5th International Conference on Management, Leadership and Governance (ICMLG) for helpful comments.

\section{Competing interests}

The authors have declared that no competing interests exist.

\section{Author's contributions}

T.M.-M. conceived and designed the analysis, collected the data, performed the analysis and wrote the article.

\section{Funding information}

This research received no specific grant from any funding agency in the public, commercial or not-for-profit sectors.

\section{Data availability statement}

Data sharing is not applicable to this article as no new data were created.

\section{Disclaimer}

The views and opinions expressed in this article are those of the authors and do not necessarily reflect the official policy or position of any affiliated agency of the authors.

\section{References}

Abad, P., Ferreras, R., \& Robles, M.D. (2018). Intra-Industry transfer effects of credit risk news: Rates versus unrated rivals. The British Accounting Review. https://doi. org/10.1016/j.bar.2018.12.002

Abad-Romero, P., \& Robles-Fernandez, M.D. (2006). Risk and return around bond rating changes: New evidence from the Spanish stock market. Journal of Business Finance \& Accounting, 33(5-6), 885-908. https://doi.org/10.1111/j.1468-5957.2006.00608.x

Abdeldayem, M.M., \& Nekhili, R. (2016). Credit rating changes and stock market reaction in the Kingdom of Bahrain. International Journal of Economics and Finance, 8(8), 23. https://doi.org/10.5539/ijef.v8n8p23
Amato, J.D., \& Furfine, C.H. (2004). Are credit ratings procyclical? Journal of Banking \& Finance, 28(11), 2641-2677. https://doi.org/10.1016/j.jbankfin.2004.06.005

Ashbaugh-Skaife, H., Collins, D.W., \& LaFond, R. (2006). The effects of corporate governance on firms' credit ratings. Journal of Accounting and Economics, 42(1), 203-243. https://doi.org/10.1016/j.jacceco.2006.02.003

Avramov, D., Chordia, T., Jostova, G., \& Philipov, A. (2009). Credit ratings and the crosssection of stock returns. Journal of Financial Markets, 12(3), 469-499. https://doi. org/10.1016/j.finmar.2009.01.005

Bhojraj, S., \& Sengupta, P. (2003). Effect of corporate governance on bond ratings and yields: The role of institutional investors and outside directors. The Journal of Business, 76(3), 455-475. https://doi.org/10.1086/344114

Caton, G.L., \& Goh, J. (2003). Are all rivals affected equally by bond rating downgrades? Review of Quantitative Finance and Accounting, 20(1), 49-62. https://doi. org/10.1023/A:1022135605941

Chi, L.C., \& Tang, T.C. (2008). The response of industry rivals to announcements of reorganization filing. Economic Model, 25(1), 13-23. https://doi.org/10.1016/j. econmod.2007.04.008

Corrado, C.J. (2011). Event studies: A methodology review. Accounting \& Finance, 51(1), 207-234. https://doi.org/10.1111/j.1467-629X.2010.00375.x

Creighton, A., Gower, L., \& Richards, A.J. (2007). The impact of rating changes in Australian financial markets. Pacific-Basin Finance Journal, 15(1), 1-17.https:// doi.org/10.1016/j.pacfin.2006.04.003

De Haan, J., \& Amtenbrink, F. (2011). Credit rating agencies. DNB working paper No 278. Retrieved n.d., from https://papers.ssrn.com/sol3/papers.cfm?abstract id $=1760951$.

Dichev, I.D., \& Piotroski, J.D. (2001). The long-run stock returns following bond ratings changes. The Journal of Finance, 56(1), 173-203. https://doi.org/10.1111/00221082.00322

Ederington, L.H., Yawitz, J.B., \& Roberts, B.E. (1987). The informational content of bond ratings. Journal of Financial Research, 10(3), 211-226. https://doi.org/ 10.1111/j.1475-6803.1987.tb00492.x

Ferreira, M.A., \& Gama, P.M. (2007). Does sovereign debt ratings news spill over to international stock markets? Journal of Banking \& Finance, 31(10), 3162-3182. https://doi.org/10.1016/j.jbankfin.2006.12.006

Goh, J.C., \& Ederington, L.H. (1993). Is a bond rating downgrade bad news, good news, or no news for stockholders? The Journal of Finance, 48(5), 2001-2008. https:// doi.org/10.1111/j.1540-6261.1993.tb05139.x

Graham, J.R., \& Harvey, C.R. (2001). The theory and practice of corporate finance: Evidence from the field. Journal of Financial Economics, 60(2), 187-243. https:// doi.org/10.1016/S0304-405X(01)00044-7

Hand, J.R., Holthausen, R.W., \& Leftwich, R.W. (1992). The effect of bond rating agency announcements on bond and stock prices. The Journal of Finance, 47(2), 733-752. https://doi.org/10.1111/j.1540-6261.1992.tb04407.x

Harrington, S.E., \& Shrider, D.G. (2007). All events induce variance: Analyzing abnormal returns when effects vary across firms. Journal of Financial and Quantitative Analysis, 42(01), 229-256. https://doi.org/10.1017/S002210900000226X

Hite, G., \& Warga, A. (1997). The effect of bond-rating changes on bond price performance. Financial Analysts Journal, 53(3), 35-51. https://doi.org/10.2469/ faj.v53.n3.2083

Jorion, P., \& Zhang, G. (2007). Information effects of bond rating changes: The role of the rating prior to the announcement. Journal of Fixed Income, 16(4), 45-59 https://doi.org/10.3905/jfi.2007.683317

Kenjegaliev, A., Duygun, M., \& Mamedshakhova, D. (2016). Do rating grades convey important information: German evidence? Economic Modelling, 53(February), 334-344. https://doi.org/10.1016/j.econmod.2015.11.021

Kim, Y., \& Sohn, S.Y. (2008). Random effects model for credit rating transitions. European Journal of Operational Research, 184(2), 561-573. https://doi. org/10.1016/j.ejor.2006.12.007

Kisgen, D.J. (2006). Credit ratings and capital structure. The Journal of Finance, 61(3), 1035-1072. https://doi.org/10.1111/j.1540-6261.2006.00866.x

Kraussl, R. (2005). Do credit rating agencies add to the dynamics of emerging market crises? Journal of Financial Stability, 1(3), 2005. Retrieved n.d., from https://ssrn. com/abstract $=443489$

Livingston, M., Poon, W.P., \& Zhou, L. (2018). Are Chinese credit ratings relevant? A study of the Chinese bond market and credit rating industry. Journal of Banking and Finance, 87(February), 216-232.

MacKinlay, A.C. (1997). Event studies in economics and finance. Journal of Economic Literature, 35(1), 13-39.

Marangos, J. (2003). Price liberalization, monetary and fiscal policies for transition economies: A post Keynesian perspective. Journal of Post Keynesian Economics, 25(3), 449.

McWilliams, A., \& Siegel, D. (1997). Event studies in management research: Theoretical and empirical issues. Academy of Management Journal, 40(3), 626-657. https:// doi.org/10.5465/257056

Micu, M., Remolona, E.M., \& Wooldridge, P.D. (2006). The price impact of rating announcements: Which announcements matter? BIS working paper 207. Bank of International Settlement, Basel.

Mittoo, U.R., \& Zhang, Z. (2008). The capital structure of multinational corporations: Canadian versus US evidence. Journal of Corporate Finance, 14(5), 706-720. https://doi.org/10.1016/j.jcorpfin.2008.09.012

Mokoteli-Mokoaleli, T., Taffler, R.T., \& Agarwal, V. (2009). Behavioral bias and conflicts of interest analysts stock recommendations. Journal of Business, Finance \& Accounting, 36(May), 384-418. https://doi.org/10.1111/j.1468-5957.2009.02125.x 
Poornima, B., Umesh, N.P., \& Reddy, Y. (2015). The impact of changes in credit ratings on stock returns. IUP Journal of Financial Risk Management, 12(3), 52.

Rogers, D., Mendes-da-Silva, W., \& Rogers, P. (2016). Credit rating change and capital structure in Latin America. BAR-Brazilian Administration Review, 13(2), 1-22. https://doi.org/10.1590/1807-7692bar2016150164
Ryan, P.A., Villupuram, S.V., \& Zygo, J.G. (2017). The value of credit rating changes across economic cycles. Journal of Economics and Business, 92 (July-August), 1-9. https://doi.org/10.1016/j.jeconbus.2017.05.003

Wakeman, L.M. (1981). The real function of bond rating agencies. Chase Financia Quarterly, 1(1), 18-26. 